УДК 343.131 .3

DOI https://doi.org/10.32849/2663-5313/2021.2.45

\title{
Наталія Кіцен,
}

канд. юрид. наук, дочент,

доцент кафедри кримінальної юстиціі

Чернівецького юридичного інституту

Начіонального університету «Одеська юридична академія»

\section{ОБМЕЖЕННЯ ЗАСАДИ БЕЗПОСЕРЕДНОСТІ ДОСЛІДЖЕННЯ ПОКАЗАНЬ, РЕЧЕЙ І ДОКУМЕНТІВ ПІД ЧАС СУДОВОГО РОЗГЛЯДУ КРИМІНАЛЬНОГО ПРОВАДЖЕННЯ В ПЕРШІЙ ІНСТАНЦІЇ}

Стаття присвячена розкриттю обмежень засади безпосередності дослідження показань, речей і документів під час судового розгляду кримінального провадження в першій інстаниії.

Обгрунтовано, що ї обмеження встановлюються нормами кримінального процесуального закону, які передбачають винятки із загального правила щодо особистого сприйняття судом доказів. Доведено, що насамперед такі винятки стосуються випадків, за яких суд вправі приймати як доказ показання, речі та документи, що не були предметом його безпосереднього дослідження.

3'ясовано, що засада безпосередності дослідження показань, речей і документів не є абсолютною та під час судового розгляду кримінального провадження в першій інстаниї підлягає застосуванню з урахуванням обмежень, встановлених нормами кримінального процесуального закону. Встановлено, що до таких обмежень належать: 1) отримання та використання судом як доказу показань з чужих слів; 2) отримання та використання судом як доказу показань свідка, потерпілого, отриманих у ході його допиту під час досудового розслідування в судовому засіданні; 3) отримання та використання судом показань свідка, потерпілого шляхом проведення його допиту з використанням технічних засобів з іншого приміщення або в інший спосіб, що унеможливлює його ідентифікацію, у тому числі зі створенням акустичних перешкод у разі, якщо існує загроза ідентифікащї голосу свідка; 4) отримання та використання судом документів, визначених пунктами 1-3 частини 2 та частиною 5 статті 99 КПК України; 5) отримання та використання судом у порядку частини 5 статті 99 КПК України доказів для підтвердження достовірності документа за відсутності його оригіналу; 6) отри мання та використання судом доказів для підтвердження достовірності речових доказів у разі знищення останніх, їх передачі для реалізачії або технологічної переробки чи передачі Начіональному агентству України з питань виявлення, розиуку та управління активами, одержаними від корупиійних та інших злочинів, для здійснення заходів з управління ними з метою забезпечення їх збереження або збереження їхноої економічної вартості, або для реалізаиії; 7) постановлення судом ухвали про проведення слідчих (розшукових) дій або тимчасового доступу до речей і документів; 8) постановлення судом ухвали, яка передбачає проведення скороченого судового розгляду.

Ключові слова: засади кримінального провадження, безпосередність дослідження доказів, показання, речові докази, документи, обмеження засади безпосередності.

Постановка проблеми. Кримінальний процесуальний закон закріплює широке коло загальних засад кримінального провадження, яким повинні відповідати його зміст і форма, та відносить до їх числа безпосередність дослідження показань, речей і документів (частина 1 статті 7 КПК України). Зміст цієї засади у цілому визначається статтею 23 КПК України, аналіз якої до елементів її змісту дозволяє віднести: 1) докази досліджуються судом безпосередньо, у тому числі шляхом отримання показань учасників кримінального провадження в усній формі; 2) відомості, що містяться в показаннях, речах і докумен- тах, які не були предметом безпосереднього дослідження суду, не можуть бути визнані доказами, за винятком випадків, передбачених КПК України; 3) суд може прийняти як доказ показання осіб, які не дають їх безпосередньо в судовому засіданні, лише у випадках, передбачених КПК України; 4) з метою реалізації права сторони захисту на допит перед незалежним та неупередженим судом сторона обвинувачення зобов'язана забезпечити присутність під час судового розгляду свідків обвинувачення [1]. Наведені елементи змісту засади безпосередності дослідження показань, речей і документів 
свідчать, що безпосереднє дослідження доказів судом під час судового розгляду кримінального провадження в першій інстанції є загальним правилом, з якого норми кримінального процесуального закону встановлюють низку винятків. Відсильний характер норм статті 23 КПК України зумовлюе необхідність звернення до аналізу інших норм кримінального процесуального закону, присвячених закріпленню випадків, у яких суд першої інстанції вправі приймати як доказ показання, речі та документи, що не були предметом його безпосереднього дослідження.

Аналіз останніх досліджень і публікацій. Теоретичні питання, пов'язані з визначенням поняття та змісту засади безпосередності дослідження показань, речей і документів та її місця у системі засад кримінального провадження, і практичні проблеми їі реалізації під час досудового розслідування та судового розгляду були предметом дослідження широкого кола вітчизняних і зарубіжних вчених. Так, до них зверталися В.К. Волошина, Ю.М. Грошевий, Л.В. Карабут, Т.В. Каткова, М.В. Колосова, В.Я. Лівшиць, Д.А. Мезінов, Т.Ю. Ничипоренко, 3.І. Сарбаєв, А.М. Склізков, Г.П. Тимченко, В.Д. Шундіков, М.М. Ясинок та інші науковці, праці яких заклали наукове підгрунтя для висвітлення теоретичних і вирішення практичних аспектів зазначеної проблематики. Поряд із цим комплексні дослідження засади безпосередності дослідження показань, речей і документів проводилися С.О. Гриненком, який встановлював іiї зміст та розкривав особливості реалізації у досудових стадіях кримінального процесу (за КПК України 1960 року) [2], та О.Г. Дехтяр, яка охарактеризувала зміст цієї засади та особливості її реалізації як під час досудового розслідування, так і в ході судового розгляду в першій інстанції та судового провадження з перегляду судових рішень [3] Проте вченими недостатньо уваги присвячено визначенню кола й розкриттю змісту випадків, у яких суд першої інстанції вправі приймати як доказ показання, речі та документи, що не були предметом його безпосереднього дослідження.

Метою даної статті є розкриття обмежень засади безпосередності дослідження показань, речей і документів під час судового розгляду кримінального провадження в першій інстанції.

Виклад основного матеріалу. Засада безпосередності дослідження показань, речей і документів зобов'язує суд під час судового розгляду в першій інстанції дослідити ї шляхом проведення відповідних проце- суальних дій, коло яких визначається нормами § 3 «Процедура судового розгляду» глави 28 «Судовий розгляд» КПК України: допиту обвинуваченого, потерпілого, свідків, експерта, пред'явлення для впізнання, огляду речових доказів, дослідження протоколів слідчих (розшукових) дій і документів, відтворення звукозаписів і відеозаписів, огляду у виняткових випадках певного місця (статті 351-361). У цьому аспекті засада безпосередності дослідження показань, речей і документів забезпечує з'ясування обставин, встановлених під час кримінального провадження, та їх перевірку за допомогою доказів, а також створює необхідні передумови для подальшої оцінки судом доказів у зв'язку з ухваленням судового рішення.

Обмеження засади безпосередності дослідження показань, речей і документів під час судового розгляду кримінального провадження в першій інстанції встановлюються нормами кримінального процесуального закону, які передбачають винятки із загального правила щодо особистого сприйняття судом доказів. Насамперед такі винятки стосуються випадків, у яких суд вправі приймати як доказ показання, речі та документи, що не були предметом його безпосереднього дослідження.

Стосовно показань норми КПК України закріплюють три обмеження засади безпосередності дослідження показань, речей і документів під час судового розгляду кримінального провадження в першій інстанції.

Перше 3 них стосується можливості отримання та використання судом як доказу показань 3 чужих слів, якими згідно $з$ частиною 1 статті 97 КПК України є висловлювання, здійснене в усній, письмовій або іншій формі, щодо певного факту, яке грунтується на поясненні іншої особи [1]. При цьому обмеження засади безпосередності дослідження показань, речей і документів наявне лише в тих випадках, в яких суд позбавлений можливості допитати особу, яка надала первинні пояснення, з підстав, передбачених частиною 3 статті 97 КПК України. Так, відповідно до вказаної норми, суд має право визнати неможливим допит особи, якщо вона: 1) відсутня під час судового засідання внаслідок смерті або через тяжку фізичну чи психічну хворобу; 2) відмовляється давати показання в судовому засіданні, не підкоряючись вимозі суду дати показання; 3) не прибуває на виклик до суду, а ï місцезнаходження не було встановлено шляхом проведення необхідних заходів розшуку; 4) перебуває за кордоном та відмовляється давати показання [1]. Водночас частина 2 статті 97 КПК України закріплює, що суд має право визнати 
допустимим доказом показання з чужих слів незалежно від можливості допитати особу, яка надала первинні пояснення, у виняткових випадках, якщо такі показання є допустимим доказом згідно з іншими правилами допустимості доказів [1]. Піддаючи наведену норму в частині надання суду права визнати допустимим доказом показання з чужих слів за наявності можливості допитати особу, яка надала первинні пояснення, обгрунтованій критиці, Н.З. Рогатинська зазначає, що вона порушує засаду безпосередності дослідження показань, речей і документів, з урахуванням якої суд зобов'язаний безпосередньо дослідити відомості, що містяться в поясненнях особи, на які посилається допитаний у судовому засіданні свідок чи потерпілий [4, с. 124]

Друге обмеження засади безпосередності дослідження показань, речей і документів під час судового розгляду кримінального провадження щодо показань стосується можливості отримання та використання судом як доказу показань свідка, потерпілого, отриманих у ході його допиту під час досудового розслідування в судовому засіданні. Так, частина 1 статті 225 КПК України передбачає, що у виняткових випадках, пов'язаних із необхідністю отримання показань свідка чи потерпілого під час досудового розслідування, якщо через існування небезпеки для життя і здоров'я свідка чи потерпілого, їх тяжкої хвороби, наявності інших обставин, що можуть унеможливити їх допит в суді або вплинути на повноту чи достовірність показань, сторона кримінального провадження, представник юридичної особи, щодо якої здійснюється провадження, мають право звернутися до слідчого судді із клопотанням провести допит такого свідка чи потерпілого в судовому засіданні, в тому числі одночасний допит двох чи більше вже допитаних осіб. У цьому випадку допит свідка чи потерпілого здійснюється у судовому засіданні в місці розташування суду або перебування хворого свідка, потерпілого в присутності сторін кримінального провадження з дотриманням правил проведення допиту під час судового розгляду [1]. Застосування зазначеного порядку отримання показань свідка, потерпілого, який у доктрині кримінального процесу отримав назву «депонування доказів» [5, с. 279; 6, с. 392], уможливлюе подальше ї використання судом на підставах і в порядку, визначених частинами 3-5 статті 225 КПК України..

Третє обмеження досліджуваної засади у ході судового розгляду щодо показань стосується можливості отримання та використання судом показань свідка, потерпілого шляхом проведення його допиту з використанням технічних засобів 3 іншого приміщення або в інший спосіб, що унеможливлює його ідентифікацію. Так, частина 9 статті 352 КПК України закріплює, що у виняткових випадках для забезпечення безпеки свідка, який підлягає допиту, суд за власною ініціативою або за клопотанням сторін кримінального провадження чи самого свідка постановляє вмотивовану ухвалу про проведення допиту свідка з використанням технічних засобів з іншого приміщення, у тому числі за межами приміщення суду, або в інший спосіб, що унеможливлюе його ідентифікацію та забезпечує сторонам кримінального провадження можливість ставити запитання і слухати відповіді на них. У разі якщо існує загроза ідентифікації голосу свідка, допит може супроводжуватися створенням акустичних перешкод [1]. 3 урахуванням частини 2 статті 353 КПК України вказана норма поширюється й на допит потерпілого.

На обмеження в останньому 3 наведених випадків засади безпосередності дослідження показань, речей і документів під час судового розгляду кримінального провадження та відсутність у результаті його застосування порушення цієї засади звертається увага в судовій практиці. Так, Верховний Суд в постанові від 19 листопада 2019 року у справі № 750/5745/15-к (провадження № 51-10195км18) зазначає, що засаді безпосередності, як і будь-якій іншій загальній засаді, притаманна певна гнучкість у ході застосування в конкретних обставинах. Залежно від обставин ця засада реалізується в різних формах, оскільки суд має узгоджувати їі з іншими засадами кримінального процесу та/або легітимними інтересами суспільства чи окремих осіб. Наприклад, принцип безпосередності зазнає певних легітимних обмежень у разі допиту особи, до якої застосовані заходи безпеки або яка відсутня безпосередньо в залі судового засідання (стаття 232 КПК України), і такі легітимні обмеження не можна вважати порушенням принципу безпосередності [7].

Стосовно документів обмеження засади безпосередності дослідження показань, речей i документів під час судового розгляду кримінального провадження в першій інстанції закріплюються нормами пунктів 1-3 частини 2 та частиною 5 статті 99 КПК України.

По-перше, пункти 1-3 частини 2 вказаної статті передбачають, що до документів, за умови наявності в них відомостей, передбачених частиною першою цієї статті, можуть належати: 1) матеріали фотозйомки, 
звукозапису, відеозапису та інші носії інформації (у тому числі електронні); 2) матеріали, отримані внаслідок здійснення під час кримінального провадження заходів, передбачених чинними міжнародними договорами згоду на обов'язковість яких надано Верховною Радою України; 3) складені в порядку, передбаченому цим Кодексом, протоколи процесуальних дій та додатки до них, а також носії інформації, на яких за допомогою технічних засобів зафіксовано процесуальні дії [1]. Аналізуючи наведені норми, О.Г. Дехтяр обгрунтовано наголошує, що під час дослідження документів, передбачених п. п. 1-3 ч. 2 ст. 99 КПК України, сприйняття суду має опосередкований характер, що пояснюється тим, що він сприймає інформацію, процесуальна форма якій надана, як правило, учасником кримінального провадження (оперативним підрозділом, слідчим прокурором), який безпосередньо ії сприймав [3, с. 119-120].

По-друге, частина 5 статті 99 КПК України закріплює, що для підтвердження змісту документа можуть бути визнані допустимими й інші відомості, якщо: 1) оригінал документа втрачений або знищений, крім випадків, якщо він втрачений або знищений $з$ вини потерпілого або сторони, яка його надає; 2) оригінал документа не може бути отриманий за допомогою доступних правових процедур; 3) оригінал документа знаходиться у володінні однієї зі сторін кримінального провадження, а вона не надае його на запит іншої сторони [1]. Тобто зазначена норма уможливлює дослідження під час судового розгляду кримінального провадження в першій інстанції та подальше використання судом доказів, спрямованих на підтвердження достовірності документа за відсутності його оригіналу.

Стосовно речових доказів обмеження засади безпосередності дослідження показань, речей і документів під час судового розгляду кримінального провадження в першій інстанції грунтуються на частині 6 статті 100 КПК України. Так, норми частини 6 вказаної статті передбачають можливість: 1) знищення, передачі для реалізації або технологічної переробки речових доказів, що не містять слідів кримінального правопорушення, у вигляді предметів, великих партій товарів, зберігання яких через громіздкість або з інших причин неможливе без зайвих труднощів або витрати із забезпечення спеціальних умов зберігання яких сумірні з їхньою вартістю, а також речові докази у вигляді товарів або продукції, що піддаються швидкому псуванню; 2) передачі речових доказів вартістю понад 200 розмірів прожиткового мінімуму для працездатних осіб, якщо це можливо без шкоди для кримінального провадження Національному агентству України з питань виявлення, розшуку та управління активами, одержаними від корупційних та інших злочинів, для здійснення заходів з управління ними 3 метою забезпечення їх збереження або збереження їхньої економічної вартості, а також передачі зазначених вище речових доказів такої самої вартості - для їх реалізації з урахуванням особливостей, визначених законом [1]. У зв'язку з цим наведені норми створюють передумови для дослідження судом речових доказів на основі протоколів відповідних слідчих (розшукових) та інших процесуальних дій, в ході яких вони були виявлені і вилучені, а також додатків до них.

Окрім випадків, за яких суд вправі приймати як доказ показання, речі та документи, що не були предметом його безпосереднього дослідження, до винятків із засади безпосередності їх дослідження В.К. Волошина обгрунтовано відносить призначення судом слідчих (розшукових) дій під час судового провадження [8, с. 68]. Так, відповідно до частини 3 статті 333 КПК України, у разі, якщо під час судового розгляду виникне необхідність у встановленні обставин або перевірці обставин, які мають істотне значення для кримінального провадження і не можуть бути встановлені або перевірені іншим шляхом, суд за клопотанням сторони кримінального провадження має право доручити органу досудового розслідування провести певні слідчі (розшукові) дії [1]. У повному обсязі обмеження засади безпосередності дослідження показань, речей і документів має місце й у разі надання судом у порядку частини 2 статті 333 КПК України тимчасового доступу до речей і документів.

Обмеженням засади безпосередності дослідження показань, речей і документів під час судового розгляду кримінального провадження в першій інстанції є випадки проведення скороченого судового розгляду. Так, згідно з частиною 3 статті 349 КПК України суд має право, якщо проти цього не заперечують учасники судового провадження, визнати недоцільним дослідження доказів щодо тих обставин, які ніким не оспорюються [1]. У цьому разі з урахуванням частини 4 вказаної статті дослідження судом доказів обмежується допитом обвинуваченого, за винятком випадків, встановлених кримінальним процесуальним законом (відмови обвинуваченого від давання показань, його неприбуття в судове засідання та неоспорення обвинуваченим встановлених під час дізнання обставин і наявність його згоди 
з розглядом обвинувального акта щодо вчинення кримінального проступку без проведення судового розгляду).

\section{Висновки}

Наведене дозволяє дійти висновку, що засада безпосередності дослідження показань, речей і документів не є абсолютною та під час судового розгляду кримінального провадження в першій інстанції підлягає застосуванню з урахуванням обмежень, встановлених нормами кримінального процесуального закону. До таких обмежень належать: 1) отримання та використання судом як доказу показань з чужих слів (стаття 97 КПК України); 2) отримання та використання судом як доказу показань свідка, потерпілого, отриманих у ході його допиту під час досудового розслідування в судовому засіданні (стаття 225 КПК Украіни); 3) отримання та використання судом показань свідка, потерпілого шляхом проведення його допиту з використанням технічних засобів 3 іншого приміщення або в інший спосіб, що унеможливлює його ідентифікацію, у тому числі зі створенням акустичних перешкод у разі, якщо існує загроза ідентифікації голосу свідка (частина 9 статті 352 і частина 2 статті 353 КПК України); 4) отримання та використання судом документів, визначених пунктами 1-3 частини 2 та частиною 5 статті 99 КПК України; 5) отримання та використання судом у порядку частини 5 статті 99 КПК України доказів для підтвердження достовірності документа за відсутності його оригіналу; 6) отримання та використання судом доказів для підтвердження достовірності речових доказів у разі знищення останніх, їх передачі для реалізації або технологічної переробки чи передачі Національному агентству України з питань виявлення, розшуку та управління активами, одержаними від корупційних та інших злочинів, для здійснення заходів 3 управління ними 3 метою забезпечення їх збереження або збереження їхньої економічної вартості, або для реалізації (частина 6 статті 100 КПК України); 7) постановлення судом ухвали про проведення слідчих (розшукових) дій або тимчасового доступу до речей i документів (частини 2 і 3 статті 333 КПК України); 8) постановлення судом ухвали, яка передбачає проведення скороченого судового розгляду (частини 3 і 4 статті 349 КПК України). Наведені обмеження визначають особливості застосування засади безпосередності дослідження показань, речей і документів під час судового розгляду кримінального провадження в першій інстанції залежно від виду процесуального джерела доказів (показань, речових доказів і документів), їх наявності у кримінальному провадженні та його обставин, які підлягають встановленню. Водночас, внаслідок їх чіткого врегулювання нормами кримінального процесуального закону, вказані обмеження не призводять до порушення засади безпосередності дослідження показань, речей і документів під час судового розгляду кримінального провадження в першій інстанції.

\section{Список використаних джерел:}

1. Кримінальний процесуальний кодекс України від 13 квітня 2012 року № 4651-VI. URL: https://zakon.rada.gov.ua/laws/show/4651-17 (дата звернення: 11.12.2020).

2. Гриненко С.О. Реалізація принципу безпосередності у досудових стадіях кримінального процесу України : монографія. Харків : Оберіг, 2008. $220 \mathrm{c}$.

3. Дехтяр О.Г. Засада безпосередності дослідження показань, речей і документів та її реалізація у кримінальному провадженні : дис. ... канд. юрид. наук: 12.00.09. Одеса, 2013. 231 с.

4. Рогатинська Н.3. Характеристика показання як джерела доказів у кримінальному судочинстві. Науковий вісник Ужгородського наиіонального університету. Серія «Право». 2014. Вип. 24. Т. 4. С. $122-124$

5. Гловюк I. Депонування показань свідка, потерпілого за Кримінальним процесуальним кодексом України 2012 р. Юридичний вісник. 2014. № 6. С. 274-281.

6. Ковальчук С.О. Вчення про речові докази у кримінальному процесі: теоретико-правові та практичні основи : монографія. Івано-Франківськ : Супрун В.П., 2017. 618 с.

7. Постанова Верховного Суду від 19 листопада 2019 року у справі № 750/5745/15-к (провадження № 51-10195км18). URL: http:// reyestr.court.gov.ua/Review/86275852 (дата звернення: 11.12.2020).

8. Науково-практичний коментар Кримінального процесуального кодексу / за ред. С.В. Ківалова та С.I. Кравченка. Одеса : Фенікс, $2020.924 \mathrm{c}$.

Nataliia Kitsen. Restrictions of the principle of immediacy of the examination of testimony, things and documents during the trial of criminal proceedings in the first instance

The article is devoted to the disclosure of the restrictions of the principle of immediacy of the examination of testimony, things and documents during the trial of criminal proceedings in the first instance.

It is substantiated that its restrictions are established by the rules of criminal procedure law, which provide exceptions to the general rule of personal perception of evidence. It is proved that, first of all, such exceptions 
concern cases in which the court has the right to accept as evidence testimony, things and documents that were not the subject of its direct investigation.

It was found that the principle of immediacy of the examination of testimony, things and documents is not absolute and during the trial of criminal proceedings in the first instance should be applied subject to the restrictions established by the rules of criminal procedure law. It is established that such restrictions include: 1) receipt and use by the court as evidence the testimony from other people's words; 2) receipt and use by the court as evidence the testimony of a witness, a victim, obtained during his interrogation during the pre-trial investigation in court; 3) receipt and use by the court the testimony of a witness, a victim by interrogation using technical means from another rooms or in another way that makes it impossible to identify him, including the creation of acoustic interference if there is a threat of identification of the witness's voice; 4) receipt and use by the court the documents specified in paragraphs 1-3 of part 2 and part 5 of article 99 of the CPC of Ukraine; 5) receipt and use by the court in accordance with part 5 of article 99 of the CPC of Ukraine evidence to confirm the authenticity of the document in the absence of its original; 6) receipt and use by the court evidence to confirm the authenticity of material evidence in case of their destruction, their transfer for sale or technological processing or transfer to the National Agency of Ukraine for finding, tracing and management of assets derived from corruption and other crimes for implementation of measures to manage them in order to ensure their preservation or preservation of their economic value, or for destruction; 7) resolution by court the decision about conduct of investigative (search) actions or temporary access to things and documents; 8) resolution by court the decision, which provides conducting an abbreviated trial.

Key words: principles of criminal proceedings, immediacy of examination of evidence, testimony, material evidence, documents, restrictions of the principle of immediacy. 